\title{
MeChanical TUtORIng SYSTEM BASEd ON VIRTUal REALITY
}

\author{
By \\ A. E. E. ElAlfi \\ A. E. Amin \\ Dept. of Computer Science \\ Dept. of Computer Science \\ Faculty of Specific Education \\ Faculty of Specific Education \\ Mansoura University, Egypt \\ Mansoura University, Egypt \\ S. A. Shaker \\ Dept. of Computer Science \\ Faculty of Specific Education \\ Mansoura University, \\ H. A.O. dawud \\ Dept. of Computer Science \\ Faculty of Specific Education \\ Mansoura
}

Research Journal Specific Fducation

Faculty of Specific Education

gYansoura University

ISSUE NO. 54, APRIL. 2019

مجلة بعوث التربية النوعية - جامعة المنصورة

العلد الرابع والخمسون - أبريل 19. 


\section{Mechanical TUtORIng SyStem Based on Virtual Reality}
A. E. E. ElAlf $i$ *
A. E. Amin*

S. A. Shaker *
H. A.O. dawud *

\section{Abstract}

Because of the massive technical and scientific improvements ,using technical information, communications in education and scientific research appeared the urgent need to put strategies develop and reform education with the appearance of the virtual environment, electronic education and the simulation programmers based on modern technique, it has become strategically option to develop and progress education, their role in achieving the self-learning ,because of this and the difficulty of the mechanics subject in the secondary stage especially in questions and laws .The equations suggest electronic programme to explain the mechanics subject this is what the study tried to achieve through the production of educational syllabuses "curriculums" that depend on virtual environment and the simulation programmers to send information to the student .The use of virtual reality encourages students to question or inquire about real scientific facts and the imagination, the care about imagination to reach to scientific facts .Education is no longer a display "show" of information to students but it has become a source of interest for students and enjoying changing their conduct or manners.

Keywords: Learning by simulation, the virtual environment, the virtual classrooms, simulation, electronic learning ,the virtual reality, the on time electronic education, The hun timing electronic education ,the virtual learning environment.

\section{INTRODUCTION}

Augmented Reality (AR) overlays virtual Dimensional (3D) objects on the real-world and is starting to emerge in training and education [1].

${ }^{*}$ Dept. of Computer Science Faculty of Specific Education Mansoura University, Egypt 
Most current VR environments are visual experiences displayed on a computer screen [2].

use of a computer vision system to automatically determine the child's emotional state is proposed [3].

Virtual Reality Systems (IVRS), the user is completely immersed in a computer generated world, giving them the impression that they have "stepped inside" a synthetic world [4].

virtual reality is an advanced human computer interface that simulates a realistic environment and allows participants to interact with it [5].

In essence, virtual reality is simply a more imaginative way of providing a human-computer interface than the standard keyboard, mouse and screen system with which we are familiar [6].

A virtual world permits the reconfiguration of parts, composites, processes, and process conditions significantly faster and more flexibly without causing high costs [7].

visual representations and realistic a priori simulations. This will result in a significant advance in scientific progress since visual representations and realistic simulations [8].

that digital media (such as simulations, videos, interactive screen experiments or web labs) can positively impact student knowledge, skills and attitudes [9].

envelopments are wearable technologies (e.g. virtual reality devices), faster and cheaper computing power, more immersive media(e.g., augmented reality, virtual reality, mixed reality) [10].

virtual world are now becoming more widely used for teaching and learning [11].

these technologies are of high interest since the vision of fully integrating virtual labs into virtual worlds is one of the main challenges [12] 
virtual systems provide a cost-efficient way for schools and universities to organize high-quality laboratory work [13] .

\section{The paper is organized as follows.}

-The first section presents the imaginary environment to some laws in mechanics.

-Section two presents the suggested model.

-Section three presents models of the virtual environment.

-Section four presents statistics and results.

- Section five presents the conclusions.

\section{The imaginary environment for the explanation of mechanics laws.}

The virtual interactive world is tri-sides and it is a kind of communities on the internet that simulate the real environment depending on the computer. The user of this environment can interact with others to exchange experiences. Because of the abilities of the virtual world .We can setup virtual experiments that simulate the real world exactly .The trainer can inter by this experiment and the designed Scenario according to the nature of the objective or purpose-this is very useful in reflecting the reality before going down to it. The simulation is used a lot of before the field exercises like "surgical operations ,military sectors education sectors the education sectors - the civil defiance-practical experiments ".

The virtual classrooms or what are called electronic classrooms, smart classrooms or imaginary classrooms are considered the direct or in direct environment that can depend on the web or based on programs that require downloading and fixing as in the real classrooms or ordinary classrooms .The student in the virtual classrooms can participate in the direct instructions. That means that the student and the teacher can rely to the virtual classrooms at the same time. The information explosion is considered one of the helping or assisting factors in developing the virtual classrooms. The information is no longer the objective or the goal but it is important how to deliver it and benefit from it with the ability for keeping the on .Time lessons and to go back to them later and it enables or allow the 
opportunities to the teacher to meet and the on-time or no-time communication with the students to give them a remote lecture from anywhere and at any time .The next figure shows a suggested model to the virtual classroom to explain some of newton's laws in mechanics for secondary stage students.

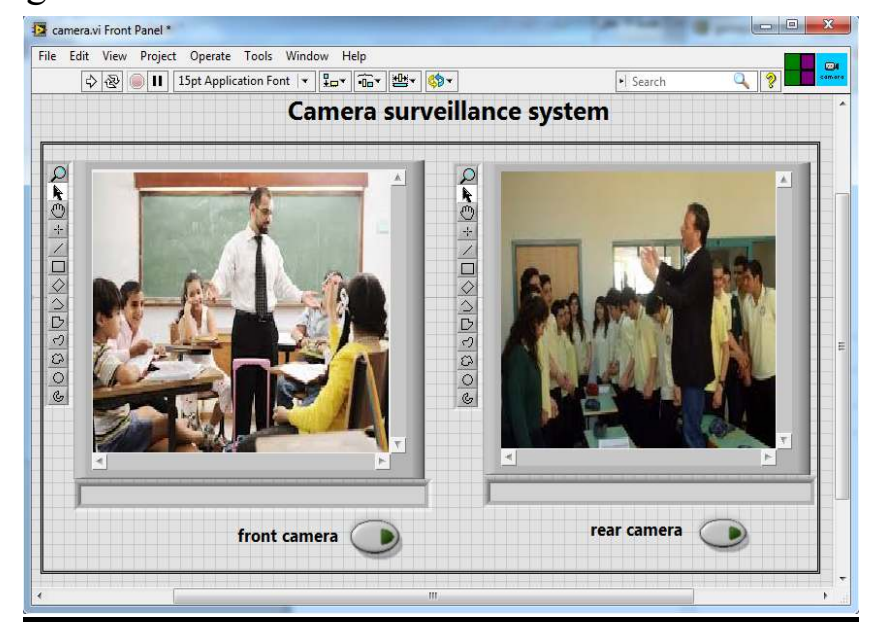

Fig 1."The main board to the virtual classroom to control by rear camera."

The Virtual Reality is a technology that allows or permit setting up similar environment to reality by the computer ,by using the screen of the computer, the doubled sound head phones and the glasses . That it depends on presenting similar image "picture" to reality in the places that people "man" can't reach to or setting them up. Simulation learning connects with this : It is an educational style that the teacher usually uses to near students to the real world which is difficult to be available to learners because of the cost of money and the human sources or the difficulty of the subject matter. So ,we can say that they are forms of learning experience; they are educational Scenarios that the teacher put the learner in directly to act reality or the real world and they suit if the principles of theoretical building "the building theory " so it develops the critical thinking and the ability evaluate the learner. 
Simulation is activities that are designed to represent "act" the real life .

They are usually educational exercises that aim at acting the real life activities mostly. It's an imitation to areal equipment .Simulation tries to act and offer the features that qualify a conduct of a system that is abstract or physical by a manner "conduct" of another system that simulates "imitates" the first . It is also an attempt to recycle an operation in artificial conditions that is similar to some extent to the natural conditions. All the previous, are electronic systems that allow interaction between the teacher by sound "voice" and picture through a complete display "show" to the content on air through interactional competition between the students and the teacher and among the students each other and among the different schools .It's known as the on-time learning and interaction and it may be no-time also. So, the virtual environment role is great and learning by simulation in mechanics as one of the alternatives for the new or modern learning methods.

\section{The opening screen for the suggested model.}

It's system that forms a tri-edged virtual environment. It allows the participant to inter the real virtual environment and deepens in it to become foaled or soaked by the virtual reality. It contains a group of options for example the display of the content of the units in the virtual environment ,the lesson objectives, tri-edged exercises on the laws of units one, two and three on two positions $2 \mathrm{~d}, 3 \mathrm{~d}$ inside the virtual environment and some tests on the units, presenting some videos to support the lessons on each unit .It also contains a group of lists for fast movement among windows" as follows" :

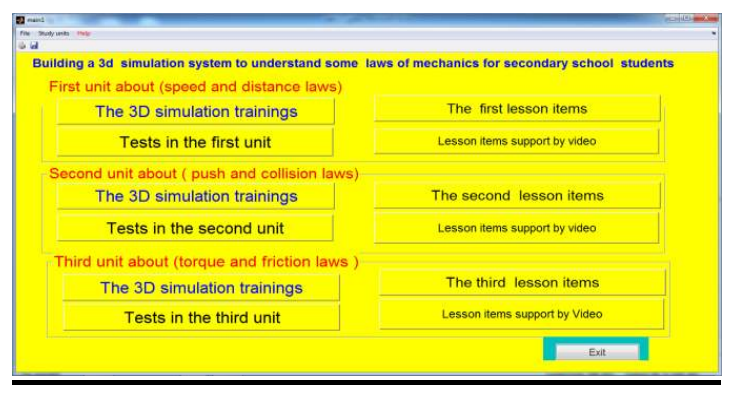

Fig 2.The user main window for the virtual environment. 
The side screen shows some or a group of tri-edged exercises on the first unit on Newton's first law.

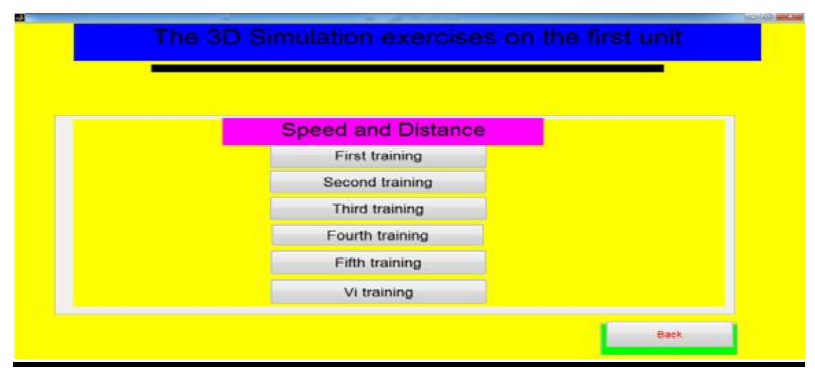

Fig 3.Alist of tri-edged exercises on unit one.

The previous window is a system that offers a lot of open e electronic exercises for the student to apply on the content of each unit and it is an operation that aims at measuring the interaction of the training plan and its efficiency and the rate or the amount of achieving the wanted objectives by showing the weakness and the strength points for the student in the scientific subject. The next screen shows training of unit one from the previous one.

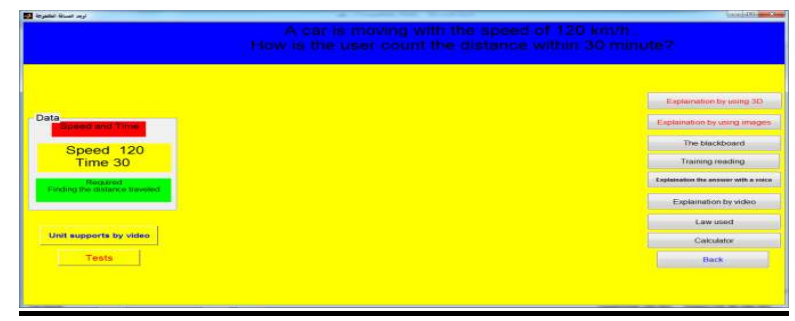

Fig4. some options that show the distance that is taken in the virtual environment.

The next screen shows the previous content when the student interacts with it in the two stages $2 \mathrm{~d}, 3 \mathrm{~d}$ inside the virtual environment. 


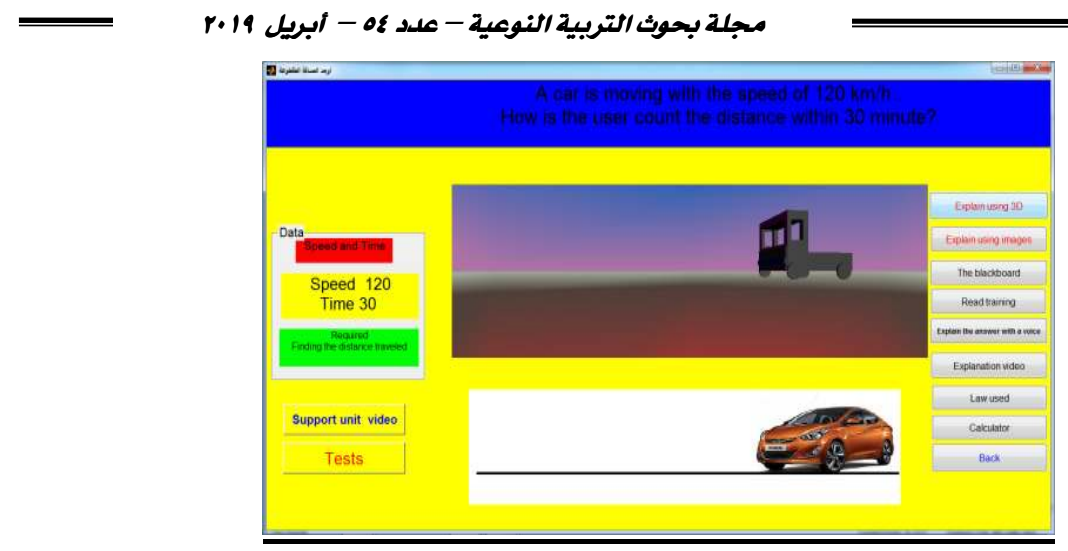

Fig 5.exmple in the two positions " double edged or tri-edged" Inside the virtual environment.

The windows contains an example from mechanics inside the virtual environment .The screen contains" start button-explanation in the tri-edged position-explanation in a double edged position -a button that show the content as smart board - a button for reading the showed questions a button for the explanation of answers with a voice only / a button for video explanation / a button for the summary of the law a calculator for student /a button to go back etc ". The next screen shows a group of exercises on unit one.

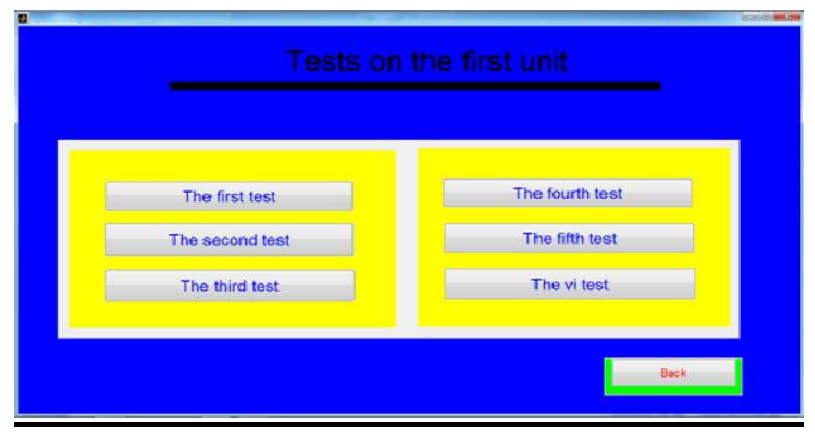

Fig 6.some exercises on unit one.

The screen shows some exercises on the content of the lesson ,objectives, concepts-the laws used in the unit -back again. 


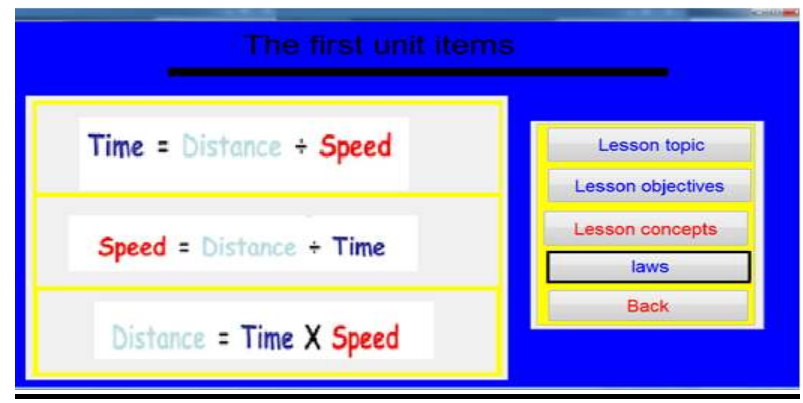

Fig 7. The content of the items of unit one.

The screen shows a group of concepts. Facts, instructions, ideas ,values , attitudes, skills, the accompany activities. The next screen shows a group of exercises to support unit one by using video.

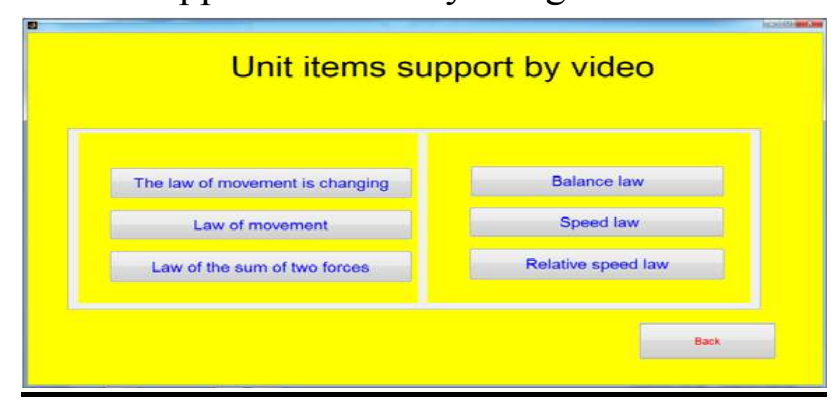

Fig 8. The main screen supports the unit items by video.

The screen presents for the student a complete and simple explanation by video for unit one in mechanics by covering of the subjects of the lessons. The next screen shows the results of one of the items by video.

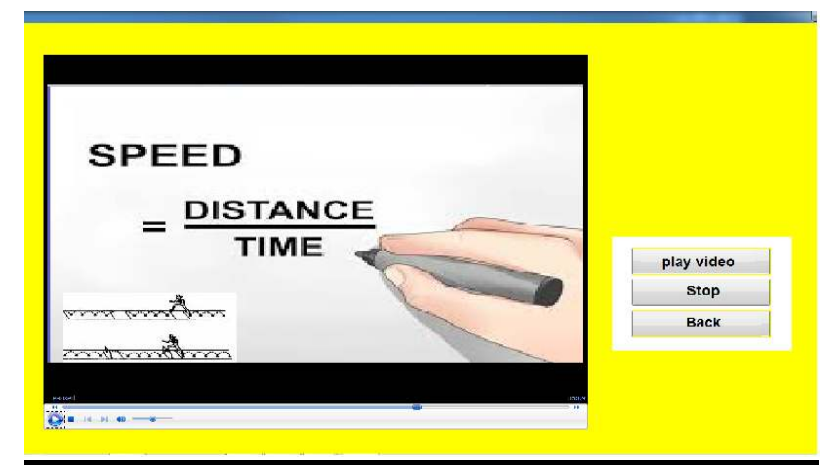

Fig 9. The side screen supports by video. 
The windows is a simple explanation to the practical subject "mechanics" on one of the items in unit one by video time 10-20 minutes. Newton put three famous and fundamental laws in studying physics and mechanics that known as newton's laws.

Three examples of simulation for the virtual reality will be shown by using Newton's laws.

1) Newton's First Law of Motion

"An object at rest remains at rest, and an object in motion remains in motion with constant velocity unless it is acted upon by an outside force".

2) Newton's Second Law of Motion

"The acceleration of an object is directly proportional to the net force acting on it and inversely proportional to its mass".

3) Newton's Third Law of Motion

"If two objects interact, the force exerted on object 1 by object 2 is equal in magnitude but opposite in direction to the force exerted on object 2 by object $1 "$.

Firstly:" Newton first law of motion: the law for self-defect or rest".

The self-rest is feature for the resistance of object to change it's state from rest to fast constant motion in straight line unless any force affects it to change its state, it means if any object is in rest, is able to change its state "from silence or rest to motion" unless an outside force affects its state. The next window shows the display of the low for the distance taken.

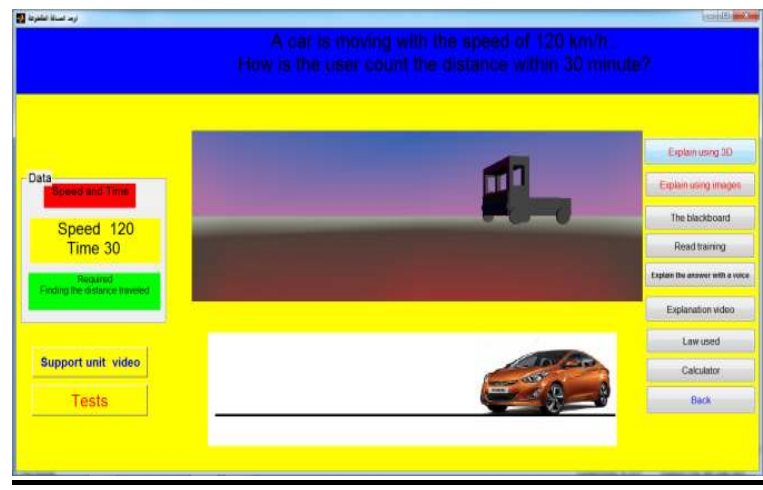

Fig10. Shows the self-defect law. 


\section{Examples :-}

If a car goes by speed of 60 meter. Find the distance during 130 seconds?

Answer:-

$$
\begin{aligned}
& \text { Distance }=\text { Speed } * \text { Time } . \\
& \text { Distance }=60 * 130=7800 \mathrm{~m} .
\end{aligned}
$$

The distance is the real route that an object takes in its motion and it's a main distance quantity non subjected, measured by the meter .The Distance $=$ Speed $*$ Time.

The law used $;$ distance $=$ speed $*$ time

$$
\mathrm{V}=\mathrm{D} / \mathrm{T} \mathrm{D}=\mathrm{V} * \mathrm{~T} \mathrm{~T}=\mathrm{D} / \mathrm{V}
$$

Where, Using vector quantities: $\mathrm{D}=$ Displacement, $\mathrm{V}=$ Velocity $\mathrm{T}=$ Time Using scalar quantities: $\mathrm{D}=$ Distance, $\mathrm{V}=$ speed, $\mathrm{T}=$ Time

\section{Secondly: Newton's second law for motion the acceleration law.}

Acceleration is known as the rate of changing the speed that goes according to the time .If the speed is measured by the meter per second. It means meter / second a second:( $\left.\mathrm{m} / \mathrm{s}^{\wedge} 2\right)$ its amount may be positive or negative or zero according to the following conditions :positive when the direction of the acceleration in the same direction of motion so the speed increases with the increase of time.

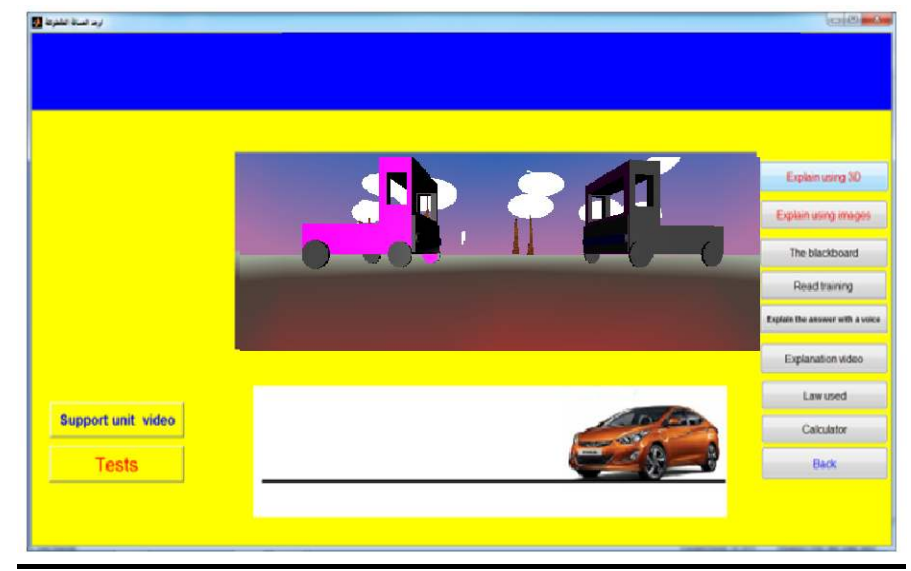

Fig11.The display of the acceleration law. 
The law used $\mathrm{T}=$ acceleration=force/Volume of the object.

$\mathrm{T}=$ acceleration of the object $\mathrm{F}=$ the force that affects the object volume

Acceleration its mark is positive when it's directed to the force mass

but slowness, it's mark is relative when it's directed to the opposite direction to the motion of the force.

\section{Example :}

a car moves in a straight line and in a constant acceleration, if the speed changes from $36 \mathrm{~km}$ /hour to $90 \mathrm{KM} /$ hour during a period of time of 20 seconds . Count the acceleration of the car in unit $\mathrm{M} / \operatorname{second}^{\wedge} 2$.

\section{The answer:-}

speed $1=36 \mathrm{KM} /$ hour.$/$ speed $2=90 \mathrm{~km} /$ hour. Time $=20$ seconds by changing the unit of speed from $\mathrm{KM} /$ hour to $\mathrm{M} /$ second.

Spead $1=(36 * 1000) /(60 * 60)$, Sped $1=10 \mathrm{M} /$ second.

Spead $2=(90 * 1000) /(60 * 60)$, Sped $2=25 \mathrm{M} /$ second.

by applying acceleration law. = Acceleration=Speed/Time.

$=($ Speed $2-$ Speed 1$) /$ Time $.20 /(25-10)=0.75 \mathrm{M} /$ secand $^{\wedge} 2$

\section{Thirdly :Newton's third low "the law of the interaction or collision.}

It is also called the action and the reflection .It says that every action has a reflection that equals it in the amount and opposite in the direction .It means if and object affects another object by ascertain force ,so the other object affects the first one by a force that is called the reflection that equals the action in amount and opposite in the direction. Each object on earth attracts other objects by a force equals positively with the total of multiplying their volume and the opposite with the square of the distance between them this law is known as the general attraction. The law used :force $=($ object $1-$ object 2$) \mathrm{F}^{\wedge} 2$

$\mathrm{F}=$ force $/ \mathrm{A}$ : the general attraction which it's quantity is

$6.673 * 10^{\wedge} 11$ Newton/M /KG2.

Volume of the object1/v2 object volume2 /distance between the two objects. 


\section{Example:-}

If the first car $\mathrm{V}$ is 5 tons, collides with another car that is 3 tons and the distance between them is $10 \mathrm{~km}$.Find the force of collision?

\section{The answer:}

force $=(16.673 * 10)(5 * 1000)(3 * 1000) \backslash(10 * 1000)=100095$ Newton.

The next windows shows the display of collision law.

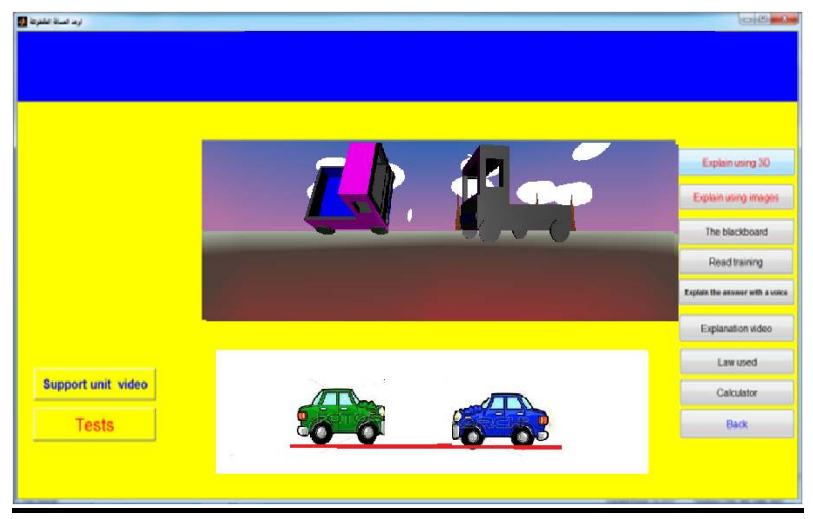

Fig12.shows the collision law in the virtual environment.

The second part "some models of virtual environments of simulation in mechanics".

The next screen shows the lean surface by studying straight and constant motion to solid object on a lean surface according to the vertical line.

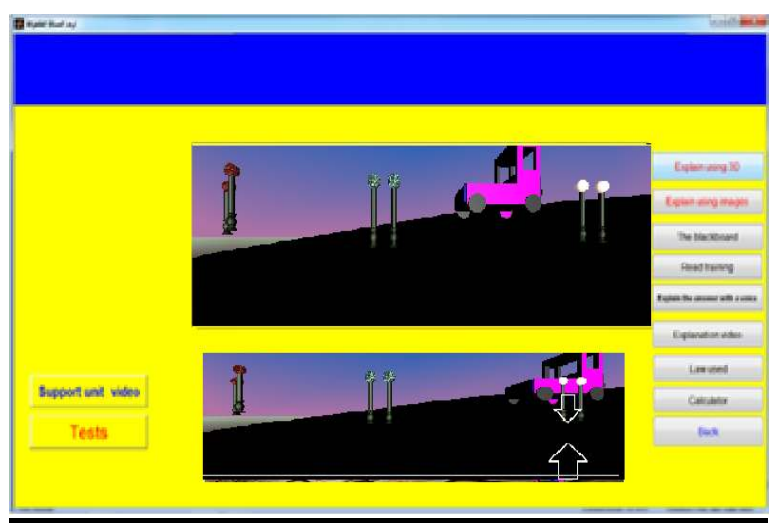

Fig 13.Applying the law on the lean surface in the virtual environment. 
The next screen shows another example on applying the law on the lean surface in the virtual environment.

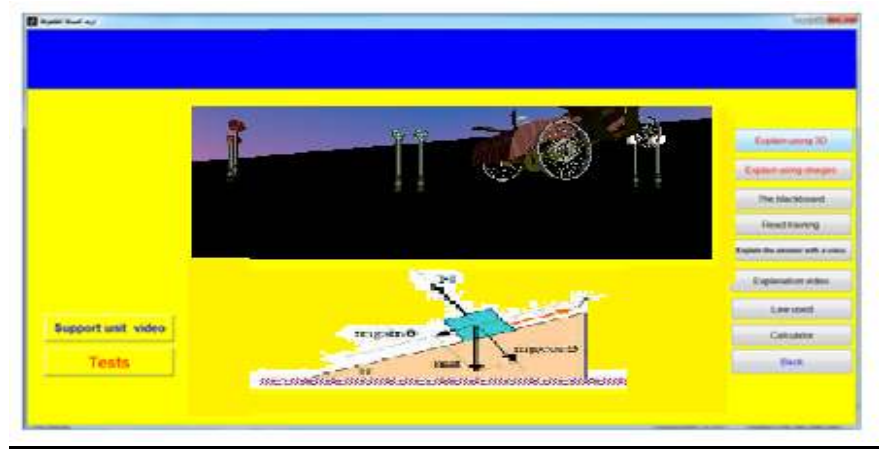

Fig 14 and 15 . Show two kinds of collisions " elastic " or inelastic.

fig 14.Applying the law on the elastic collision in the virtual environment.

The previous diagram shows the first kind of elastic collision where as the total force of motion after the collision equals the total power of force of motion before the collision. The elastic collision happens only when no part of the force "power" of the motion changes during the collision into another kind .

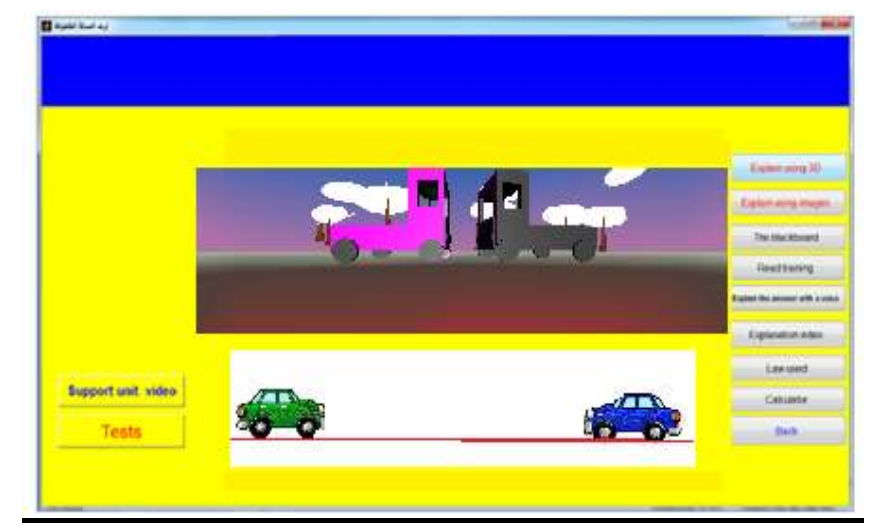

Fig15. Applying the law on the in elastic collision in the virtual environment.

The figure shows the second kind the inelastic collision, it is the opposite of the elastic collision and we can define it as the collision that doesn't keep the motion force or power because of the internal friction. 


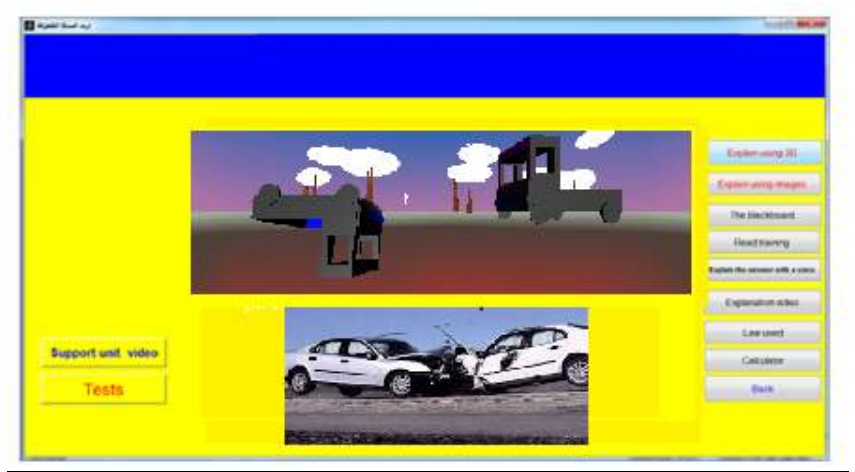

Fig16.Applying the law on the inelastic collision in the virtual environment.

It shows an example on the inelastic collision and the collision that keeps the motion quantity and doesn't keep the motion power. That means that the total of the motion "force" of objects before collision doesn't equal the total of its force after collision.

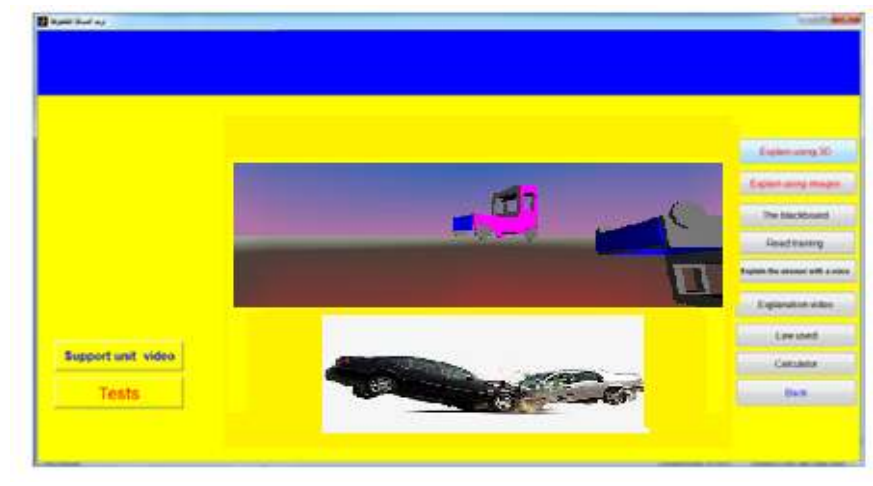

Fig 17.Applying the law of acceleration in two different direction in the virtual environment .

It shows how to measure the distance the two cars take in a certain time between two points. 

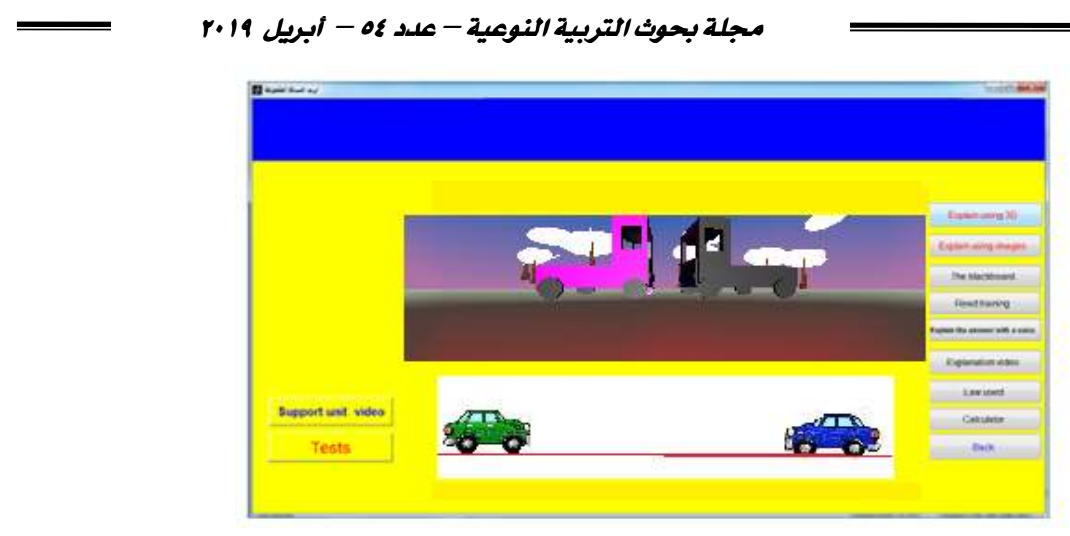

Fig 18. Applying friction law on arough surface in the virtual environment.

The screen shows the force that resists friction on a rough surface which happens when a box stickled to the surface of the earth mores, the friction will be big. The next screen shows another example of friction on a smooth surface.

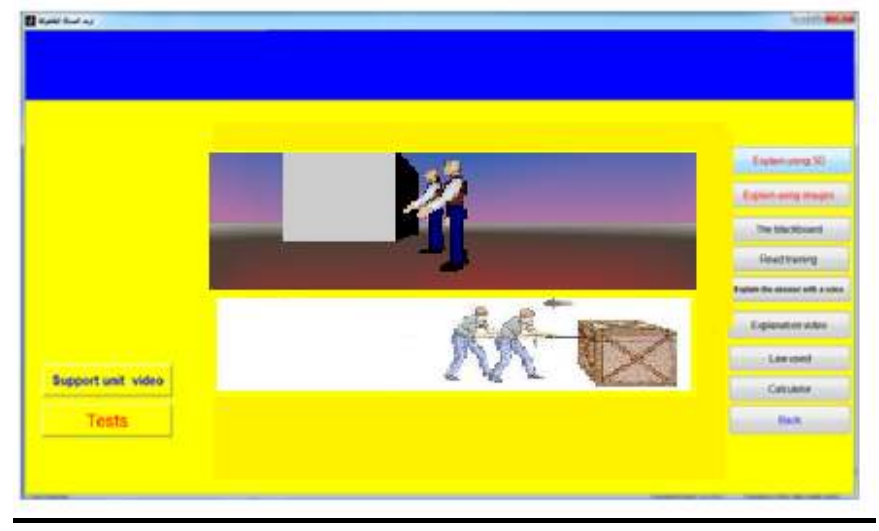

Fig 19.Applying the friction law on a smooth surface in the virtual environment.

The screen shows another example of the friction on a smooth surface with the effect of outside force "power". 


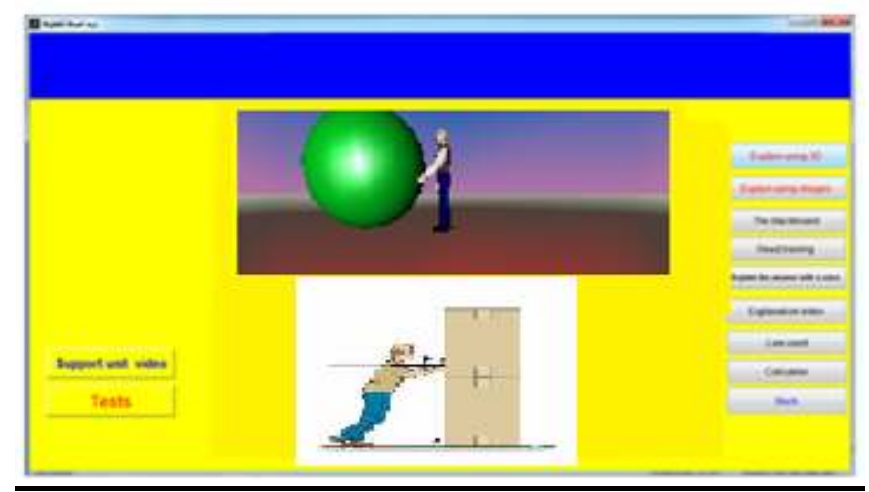

Fig20.Applying the friction law with the effect of another outside "external" force in the virtual environment.

The next screen shows the power of strength of stamina to run "turn on " the body round its center and how to measure the stamina "power" .

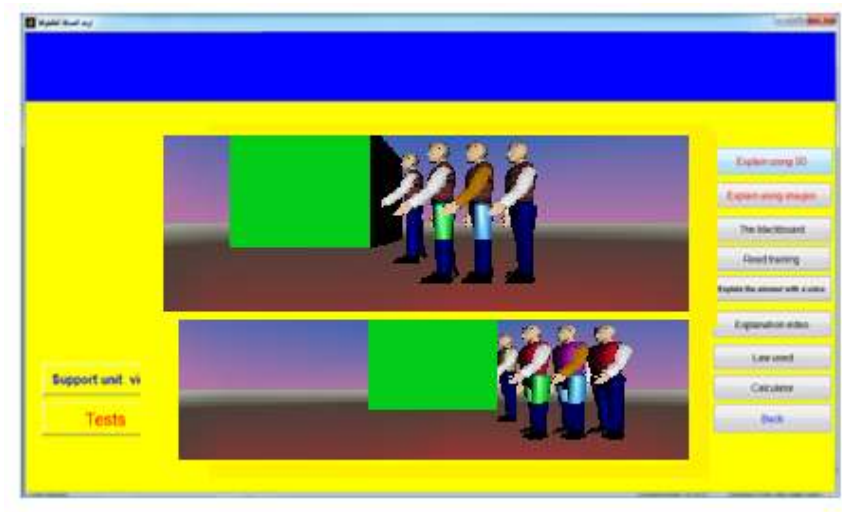

Fig 21.applying the law stamina in the virtual environment. The screen shows another kind of stamina with a lean angle. 


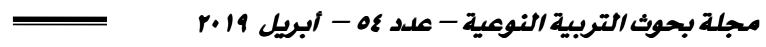

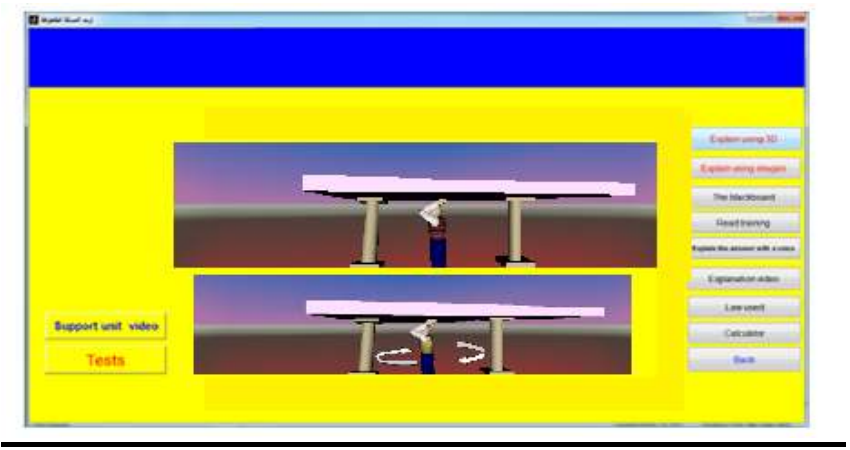

Fig 22.Applying the law of stamina with the lean angle in the virtual environment.

The screen shows the rate of speed change that is un continuous between two cars according to time.

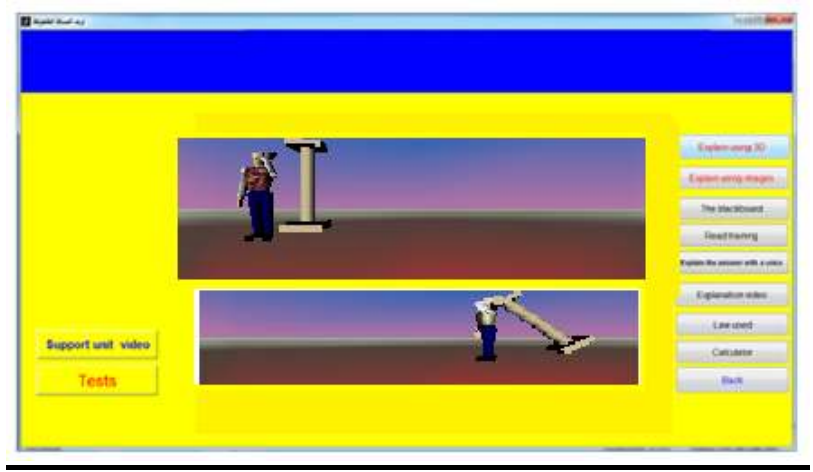

Fig 23.Applying the law of speediness in the virtual environment.

The screen shows the rate of the fixed speed between two cars a according to time.

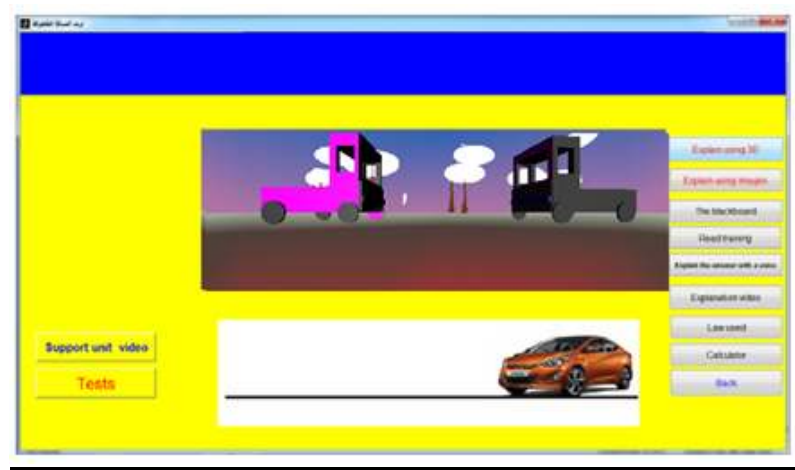

Fig24.Applying the fixed speed law in the virtual environment. 
In this study deals with the results of the research .Through the diagnostic test which prepared it by the researcher. This test was applied two times; before training the students and after their trading pre-tests and post-tests. The $\mathrm{T}$ test was also applied to investigate the student's achievements control and experimental groups.

1 - This hypothesis states that: "There are no statistically significant differences between the average scores of the students of the control group and the students of the experimental group in the pre achievement test ".

\section{The following table illustrates this:}

Table 1. It shows that there is no significance differences between the mean scores of the control and experimental groups in pretest.

Table 1. The control and experimental groups results in pretest.

\begin{tabular}{|c|c|c|c|c|c|c|c|}
\hline Study units & Groups & Number & Average & $\begin{array}{l}\text { Standard } \\
\text { deviation }\end{array}$ & T-value & $\begin{array}{l}\text { Degrees of } \\
\text { freedom }\end{array}$ & $\begin{array}{l}\text { Statistical } \\
\text { significance }\end{array}$ \\
\hline \multirow{2}{*}{ Unit 1} & $\begin{array}{c}\text { Experimen } \\
\text { tal group }\end{array}$ & 30 & 3.44 & 3.69851 & 0.1751 & \multirow{2}{*}{58} & \multirow{2}{*}{ Not } \\
\hline & $\begin{array}{c}\text { Control } \\
\text { group } \\
\end{array}$ & 30 & 2.665 & 1.26054 & & & \\
\hline \multirow{2}{*}{ Unit 2} & $\begin{array}{c}\text { Experimen } \\
\text { tal group }\end{array}$ & 30 & 3.25 & 1.56754 & 0.5181 & \multirow{2}{*}{58} & \multirow{2}{*}{ Not } \\
\hline & $\begin{array}{l}\text { Control } \\
\text { group }\end{array}$ & 30 & 3.222 & 1.91751 & & & \\
\hline \multirow{2}{*}{ Unit 3} & $\begin{array}{c}\text { Experimen } \\
\text { tal group } \\
\end{array}$ & 30 & 3.4 & 1.97559 & \multirow{2}{*}{1.4621} & \multirow{2}{*}{58} & \multirow{2}{*}{ Not } \\
\hline & $\begin{array}{c}\text { Control } \\
\text { group }\end{array}$ & 30 & 4.315 & 1.62416 & & & \\
\hline \multirow{2}{*}{ Total } & $\begin{array}{c}\text { Experimen } \\
\text { tal group }\end{array}$ & 30 & 10.09 & 7.24166 & 2.1554 & \multirow{2}{*}{58} & \multirow{2}{*}{ Not } \\
\hline & $\begin{array}{c}\text { Control } \\
\text { group }\end{array}$ & 30 & 10.202 & 4.8022 & & & \\
\hline
\end{tabular}

This table shows that there is not exist significant at $\mathrm{p} \leq 0.05$. 


\section{Results of the second hypothesis :}

2 - This hypothesis states that: "There are statistically significant differences between the average scores of the control group students and the average scores of the experimental group students in the post achievement test in favor of the experimental group."

Table 2. It shows that there is significance differences between the mean scores of the control and experimental groups in posttest.

Table 2. The control and experimental groups results in posttest.

\begin{tabular}{|c|c|c|c|c|c|c|c|}
\hline Study units & Groups & $\begin{array}{c}\text { Numbe } \\
\mathbf{r}\end{array}$ & Average & $\begin{array}{l}\text { Standard } \\
\text { deviation }\end{array}$ & T- value & $\begin{array}{l}\text { Degrees of } \\
\text { freedom }\end{array}$ & $\begin{array}{l}\text { Statistical } \\
\text { significance }\end{array}$ \\
\hline \multirow[t]{2}{*}{ Unit 1} & Experimental group & 30 & 13.3 & 0.932796 & & \multirow[t]{2}{*}{58} & \multirow[t]{2}{*}{ Yes } \\
\hline & Control group & 30 & 11.125 & 0.786444 & 7.54095 & & \\
\hline \multirow[t]{2}{*}{ Unit 2} & Experimental group & 30 & 12.225 & 1.885582 & 3.76717 & \multirow[t]{2}{*}{58} & \multirow[t]{2}{*}{ Yes } \\
\hline & Control group & 30 & 10.5 & 2.6136974 & & & \\
\hline \multirow[t]{2}{*}{ Unit 3} & Experimental group & 30 & 15.45 & 1.665756 & \multirow[t]{2}{*}{5.97615} & \multirow[t]{2}{*}{58} & \multirow[t]{2}{*}{ Yes } \\
\hline & Control group & 30 & 11.225 & 1.4015218 & & & \\
\hline \multirow[t]{2}{*}{ Total } & Experimental group & 30 & 40.975 & 4.48413 & 17.2842 & \multirow[t]{2}{*}{58} & \multirow[t]{2}{*}{ Yes } \\
\hline & Control group & 30 & 32.85 & 4.80166 & & & \\
\hline
\end{tabular}

This table shows that there is significant difference at $\mathrm{p} \leq 0.05$.

\section{Results of the third hypothesis :}

3. This hypothesis states that: "There are statistically significant differences between the average scores of the experimental group's students on the pre achievement test and post in favor of the post-test."

Table 3 It shows that there is significance differences between the mean scores of experimental groups in the pretest and posttests . 
Table 3.Experimental group results in the pretest and posttest.

\begin{tabular}{|c|c|c|c|c|c|c|c|}
\hline Study units & Groups & Number & Average & $\begin{array}{l}\text { Standard } \\
\text { deviation }\end{array}$ & T-value & $\begin{array}{c}\text { Degrees of } \\
\text { freedom }\end{array}$ & $\begin{array}{c}\text { Statistical } \\
\text { significance }(0.05)\end{array}$ \\
\hline \multirow[b]{2}{*}{ Unit 1} & pretest & 30 & 3.44 & 3.698517 & 11.35553 & \multirow[t]{2}{*}{29} & \multirow[t]{2}{*}{ Yes } \\
\hline & posttest & 30 & 13.3 & 0.932796 & & & \\
\hline \multirow{2}{*}{ Unit 2} & pretest & 30 & 3.25 & 1.567548 & 26.32739 & \multirow[t]{2}{*}{29} & \multirow[t]{2}{*}{ Yes } \\
\hline & posttest & 30 & 12.225 & 1.885582 & & & \\
\hline \multirow{2}{*}{ Unit 3} & pretest & 30 & 3.4 & 1.975594 & \multirow{2}{*}{24.51302} & \multirow[t]{2}{*}{29} & \multirow[t]{2}{*}{ Yes } \\
\hline & posttest & 30 & 15.45 & 1.665756 & & & \\
\hline \multirow{2}{*}{ Total } & pretest & 30 & 10.09 & 7.24166 & 27.61470 & \multirow[t]{2}{*}{29} & \multirow[t]{2}{*}{ Yes } \\
\hline & posttest & 30 & 40.975 & 4.48413 & & & \\
\hline
\end{tabular}

This table shows that there is significant difference at $\mathrm{p} \leq 0.05$.

\section{Results of the fourth hypothesis :}

4. This hypothesis states that: "There are statistically significant differences between the average scores of the students of the control group on the achievement test in the pre and post-test in favor of the post-test."

\section{The following table shows this:}

Table 4 It shows that there is significance differences between the mean scores of control groups in the pretest and posttests .

Table 4. Control group results in the pretest and posttest.

\begin{tabular}{|c|c|c|c|c|c|c|c|}
\hline $\begin{array}{l}\text { Study } \\
\text { units }\end{array}$ & Groups & $\begin{array}{c}\text { Numbe } \\
\mathbf{r}\end{array}$ & Average & $\begin{array}{l}\text { Standard } \\
\text { deviation }\end{array}$ & T-value & $\begin{array}{c}\text { Degrees of } \\
\text { freedom }\end{array}$ & $\begin{array}{c}\text { Statistical significance } \\
(0.05)\end{array}$ \\
\hline \multirow{2}{*}{ Unit 1} & Pretest & 30 & 2.665 & 1.220248 & 19.78976 & \multirow{2}{*}{29} & \multirow[t]{2}{*}{ Yes } \\
\hline & Posttest & 30 & 11.125 & 0.686474 & & & \\
\hline \multirow{2}{*}{ Unit 2} & Pretest & 30 & 3.222 & 1.417555 & 10.90109 & \multirow[t]{2}{*}{29} & \multirow[t]{2}{*}{ Yes } \\
\hline & Posttest & 30 & 10.5 & 1.513687 & & & \\
\hline \multirow{2}{*}{ Unit 3} & Pretest & 30 & 4.315 & 1.525581 & \multirow{2}{*}{18.62229} & \multirow[t]{2}{*}{29} & \multirow[t]{2}{*}{ Yes } \\
\hline & Posttest & 30 & 11.225 & 1.471521 & & & \\
\hline \multirow{2}{*}{ Total } & Pretest & 30 & 10.202 & 4.16338 & 49.3131 & \multirow[t]{2}{*}{29} & \multirow[t]{2}{*}{ Yes } \\
\hline & Posttest & 30 & 32.85 & 3.67168 & & & \\
\hline
\end{tabular}

This table shows that there is significant difference at $\mathrm{p} \leq 0.05$. 
Table 5 The size effect after using the program of experimental group.

Table 5. The size effect on experimental group.

\begin{tabular}{|c|c|c|c|c|c|c|c|}
\hline Groups & $\begin{array}{c}\text { Groups } \\
\text { Total }\end{array}$ & Average & $\begin{array}{l}\text { Standard } \\
\text { deviation }\end{array}$ & T-value & Eta & $\begin{array}{c}\text { Eta } \\
\text { Squared }\end{array}$ & Size Effect \\
\hline \multirow{2}{*}{$\begin{array}{c}\text { Experimental } \\
\text { group }\end{array}$} & Pretest & 10.09 & 7.24166 & \multirow{2}{*}{27.8225} & .022 & .005 & \multirow[t]{2}{*}{3.6} \\
\hline & Posttest & 40.975 & 4.484135 & & .742 & .817 & \\
\hline \multirow{2}{*}{$\begin{array}{l}\text { Control } \\
\text { group }\end{array}$} & Pretest & 10.202 & 4.163385 & \multirow{2}{*}{28.866} & .016 & .005 & \multirow[t]{2}{*}{2.3} \\
\hline & Posttest & 32.85 & 3.671684 & & .842 & .707 & \\
\hline
\end{tabular}

Table shows the size effect in using experimental group is greater than control group .

The size effect of the experimental group is (3.6) highly .Also size effect of the control group is (2.3) lower.

\section{Conclusions}

1-The techniques of the virtual reality allows news abilities to spread culture.

2-The capacity of communication at any time and everywhere.

3-The by littleness of the cost: the virtual classes don't need study places or classrooms or school play ground as well as they don't need any means of transport and costly school instruments.

4-They open a lot of fields in the debates in the virtual classrooms that help to encourage the student to share "participate without fear or fright".

5-The continuous interaction and the continuous reply and follow, all these happen electronically without adding any burdens on the school a demonstration.

6-The flexibility in doing or performing experiments. 


\section{REFERENCES}

1. Yuen, S. C. Y., Yaoyuneyong, G., \& Johnson, E. (2011). Augmented reality: An overview and five directions for AR in education. Journal of Educational Technology Development and Exchange (JETDE), 4(1), 11.

2. Billinghurst, M., \& Kato, H. (1999, March). Collaborative mixed reality. In Proceedings of the First International Symposium on Mixed Reality (pp. 261-284).

3. BENNETT, Ian. Emotion detection device \& method for use in distributed systems. U.S. Patent Application No 11/294,918, 2006.

4. Lorenzo, G., Lledó, A., Pomares, J., \& Roig, R. (2016). Design and application of an immersive virtual reality system to enhance emotional skills for children with autism spectrum disorders. Computers \& Education, 98, 192-205.

5. Sanchez-Vives, M. V., \& Slater, M. (2005). From presence to consciousness through virtual reality. Nature Reviews Neuroscience, 6(4), 332.

6. Conklin, J. (1987). Hypertext: An Introduction and SurvevJ. IEEE computer, 20(9), 17-41.

7. ElMaraghy, H., Schuh, G., ElMaraghy, W., Piller, F., Schönsleben, P., Tseng, M., \& Bernard, A. (2013). Product variety management. Cirp Annals, 62(2), 629-652.

8. Moeslund, T. B., Hilton, A., \& Krüger, V. (2006). A survey of advances in vision-based human motion capture and analysis. Computer vision and image understanding, 104(2-3), 90-126.

9. Volery, T., \& Lord, D. (2000). Critical success factors in online education. International journal of educational management, 14(5), 216-223.

10. Van Krevelen, D. W. F., \& Poelman, R. (2010). A survey of augmented reality technologies, applications and limitations. International journal of virtual reality, 9(2), 1.

11. Kneebone, R. (2003). Simulation in surgical training: educational issues and practical implications. Medical education, 37(3), 267-277.

12. Gubbi, J., Buyya, R., Marusic, S., \& Palaniswami, M. (2013). Internet of Things (IoT): A vision, architectural elements, and future directions. Future generation computer systems, 29(7), 1645-1660.

13. Morey, A. I. (2004). Globalization and the emergence of for-profit higher education. Higher education, 48(1), 131-150. 


\section{نظام التدريس الميكانيكي القائم على الواقع الافتراضي}

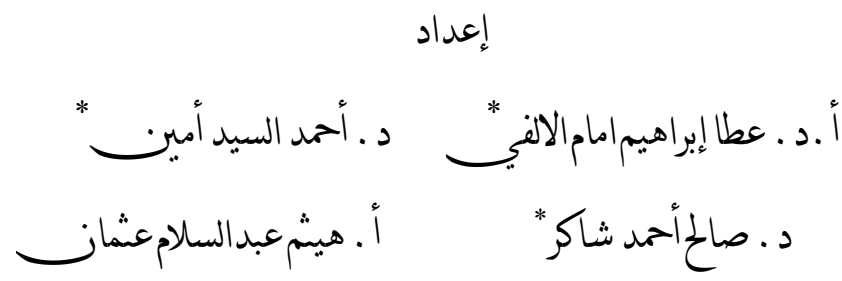

anil|

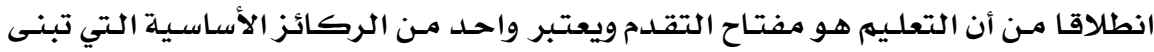

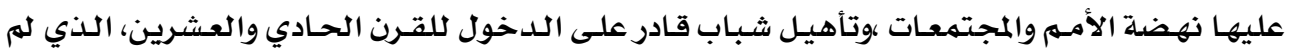

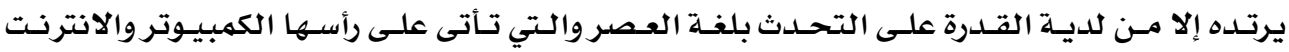

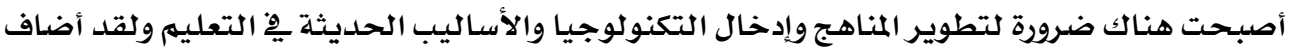

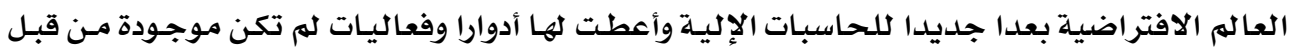

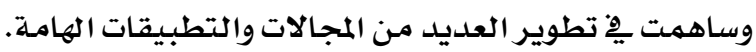

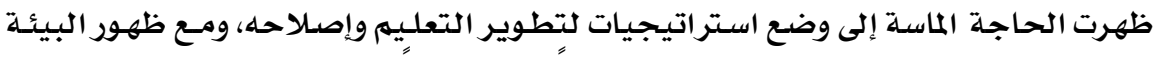

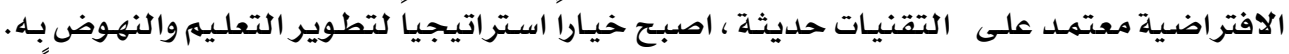

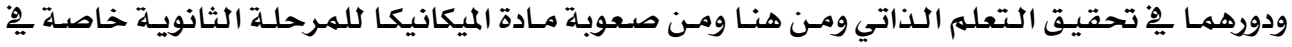

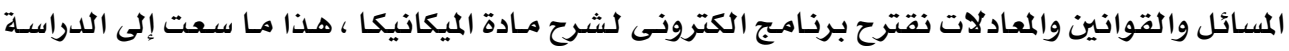

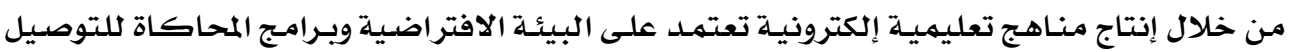

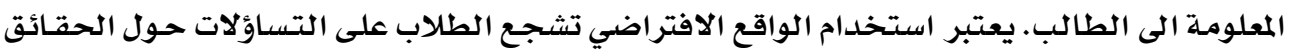

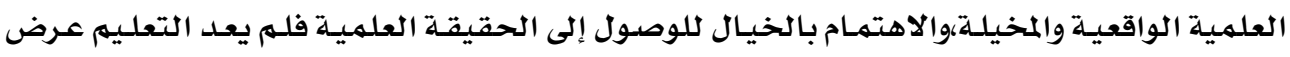

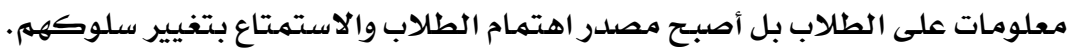

